1974

\title{
An Archaeological Survey of the Nichols Creek Channel Modification, Karnes County, Texas
}

Anne Adams Fox

Follow this and additional works at: https://scholarworks.sfasu.edu/ita

Part of the American Material Culture Commons, Archaeological Anthropology Commons, Environmental Studies Commons, Other American Studies Commons, Other Arts and Humanities Commons, Other History of Art, Architecture, and Archaeology Commons, and the United States History Commons

Tell us how this article helped you.

This Article is brought to you for free and open access by the Center for Regional Heritage Research at SFA ScholarWorks. It has been accepted for inclusion in Index of Texas Archaeology: Open Access Gray Literature from the Lone Star State by an authorized editor of SFA ScholarWorks. For more information, please contact cdsscholarworks@sfasu.edu. 


\section{An Archaeological Survey of the Nichols Creek Channel Modification, Karnes}

County, Texas

\section{Creative Commons License}

\section{(c) (1) \&}

This work is licensed under a Creative Commons Attribution-NonCommercial 4.0 International License 
AN ARCHAEOLOGICAL SURVEY OF THE

NICHOLS CREEK CHANNEL MODIFICATION,

KARNES COUNTY, TEXAS

by

Anne Adams Fox

Center for Archaeological Research

The University of Texas at San Antonio

Archaeological Survey Report, No. 5

December 15, 1974

UTSA - Center for

Archaeological Research 



\section{INTRODUCTION}

During the week of November 17-23, 1974, the author conducted an archaeological survey on Nichols Creek in the town of Kenedy, Karnes County, Texas. The survey was conducted under an agreement between the United States Department of Agriculture Soil Conservation Service (SCS) and The University of Texas at San Antonio, Center for Archaeological Research (a part of Purchase Order No. 427-TX-SCS-75). The project was under the general supervision of Dr. Thomas Hester.

The SCS proposes to channelize a major portion of the creek and of the area where it joins Escondido Creek, to prevent future flooding within the town. The purpose of the survey was to ascertain if any archaeological sites, prehistoric or historic, would be affected by the project, and to obtain an inventory of such sites where they exist. Standard archaeological procedures were followed during the course of the work, including preliminary documentary research and intensive survey in the field.

\section{PRELIMINARY RESEARCH}

Before undertaking the field survey, a search was made of the files of recorded archeological sites at the Texas Archeological Research Laboratory at Austin for sites previously documented within the modification area. 
Although no sites are recorded in the Nichols Creek Watershed, twenty-six sites are known from other parts of Karnes County. Fourteen of these fall within the scope of an archaeological survey of areas to be affected by a series of flood retarding dams in the Ecleto Creek Watershed (Crawford 1971). The most common archaeological sites within the county are open campites either on the surface or buried in alluvial stream terraces, which are identified by deposits of firecracked hearthstones, charcoal and ash, chips of flint, and occasional flint and stone artifacts. Also present are quarry or workshop sites.

Because of the location of Nichols Creek within an area of possible historic significance, thorough historical research was done in order to anticipate what type of sites might be found. In 1767 Father Jose de Solfs described a trip from LaBahia (Goliad) to San Antonio on a trail up the west side of the San Antonio River, which probably passed through this general area (Forrestal 1931: 17). Most of the 1 and bordering the San Antonio River was divided into large ranches owned by Spanish citizens of San Antonio and LaBahia during the late 17th and early 18th centuries, which ownership was taken over in this area by settlers of Polish and Irish background in the mid-19th century. At this time the commerical and social center'of the area was Helena, a town approximately $10 \mathrm{kilometers}$ north east of Nichols $\mathrm{Creek}$, an important stop on the main car road from Indianola to San Antonio, El Paso, New Mexico, and Chihuahua. With the coming of the railroad, emphasis 


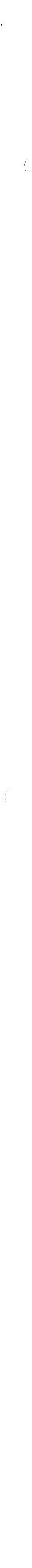


shifted west and Kenedy was founded in 1882, named for Mifflin Kenedy, local rancher and one of the financial backers of the San Antonio and Aransas Pass Railroad. The earliest settlers of the town built homes on the hill overlooking Nichols Creek, just south of the present center of town, and near the southern part of the channel modification project. According to local informants one of the first settlers and a major landowner was J.M. Nichols, for whom the creek was undoubtedly named, whose rock house was about a mile south of town (Didear 1969). In recent history, a number of processing plants have been located on land between the railroad and Nichols Creek, including a cottonseed oil plant which is no longer in operation, and some of whose buildings have been taken down or allowed to collapse, leaving various concrete slabs and piles of rubble. There also was a brief period when hot mineral wells attracted tourists to a site near the creek just north of the center of town (Didear 1969; Webb 1952).

\section{FIELD SURVEY}

Since the proposed channelization includes widening the present channel, eliminating bends in the creeks, and filling old stream channels, a thorough examination was given both banks of Nichols Creek, plus areas across which the channel will cut. The survey was begun at the southern end of the project (Station 646+10) and carried north in sections, ending at Station $752+40$.

The southermmost part of Nichols Creek, overgrown with thorny brush and mesquite, has cut a three meter-deep channel through dark, snail- 

flecked alluvial soil and into the reddish underlying stratum. Evidence of extreme flooding litters the area, including piles of 1 imbs and tree trunks and scattered 20th century trash. No indications of archaeological sites were observed.

In the section next to the abandoned processing plant are foundations of buildings and an old barn or stable of wood construction which may be affected by channel work, but are of no particular historic value.

The section of the creek bed from this point to the Southern Pacific Railroad crossing, through the center of the built-up area, has apparently been so completely disturbed by local residents as to make location of archaeological sites impossible. From the crossing to the intersection with Escondido Creek, the creek bed has been relatively undisturbed except for modern trash dumping and back-yard landscaping. Spot-checking in this area included assessment of the terrain at the intersection of the creeks. It was decided that the area is too low and too often flooded to contain any living sites within the proposed channel. The land across the bend of Escondido Creek where the channel will be cut contains no indication of historic or prehistoric occupation.

\section{RESULTS AND RECOMMENDATION}

No prehistoric archaeological sites were found within the channelization area. No historic sites of 18 th or 19 th century settlement were located, and what recent structures will be affected are not of historic importance. This is not to say, however, that there 
are no such sites in the area, either buried in the alluvial soil along the creeks, or just outside the channel itself. Therefore, caution should be taken in any work in which the disturbance of the soil is involved outside the immediate limits of the creek channels. Although no further archaeological work is recommended, it is urged that appropriate archaeological agencies be contacted should materials of prehistoric or historic significance be found during the modification process. 


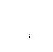




\section{BIBLIOGRAPHY}

Crawford, Daymond D.

1971 An Archeological Reconnaisance of Ecleto Creek Watershed, South Central Texas. Texas Archeological Salvage Project Survey Reports, No. 8, The University of Texas at Austin.

Didear, Hedwig Krell

1969 A History of Karnes County and 01d Helena. San Felipe Press, Austin.

Forresta1, Rev. Peter P., transcript

1931 The Solis Diary of 1767. Preliminary Studies of the Texas Catholic Historical Society, Vol. 1, No. 6.

Webb, Walter Prescott, Editor-in-chief

1952 Kenedy. In: The Handbook of Texas, Vo1. 1: 947. Texas State Historical Association, Austin. 


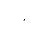

